\title{
Realizing new regional core competence : establishing a customer-oriented SME-network
}

Citation for published version (APA):

Vanhaverbeke, W. P. M. (1999). Realizing new regional core competence : establishing a customeroriented SME-network. NIBOR, Netherlands Institute of Business Organization and Strategy Research. NIBOR Research Memorandum No. 03 https://doi.org/10.26481/umanib.1999003

Document status and date:

Published: 01/01/1999

DOI:

10.26481/umanib.1999003

Document Version:

Publisher's PDF, also known as Version of record

\section{Please check the document version of this publication:}

- A submitted manuscript is the version of the article upon submission and before peer-review. There can be important differences between the submitted version and the official published version of record.

People interested in the research are advised to contact the author for the final version of the publication, or visit the DOI to the publisher's website.

- The final author version and the galley proof are versions of the publication after peer review.

- The final published version features the final layout of the paper including the volume, issue and page numbers.

Link to publication

\footnotetext{
General rights rights.

- You may freely distribute the URL identifying the publication in the public portal. please follow below link for the End User Agreement:

www.umlib.nl/taverne-license

Take down policy

If you believe that this document breaches copyright please contact us at:

repository@maastrichtuniversity.nl

providing details and we will investigate your claim.
}

Copyright and moral rights for the publications made accessible in the public portal are retained by the authors and/or other copyright owners and it is a condition of accessing publications that users recognise and abide by the legal requirements associated with these

- Users may download and print one copy of any publication from the public portal for the purpose of private study or research.

- You may not further distribute the material or use it for any profit-making activity or commercial gain

If the publication is distributed under the terms of Article $25 \mathrm{fa}$ of the Dutch Copyright Act, indicated by the "Taverne" license above, 


\title{
REALIZING NEW REGIONAL CORE COMPETENCE: ESTABLISHING A CUSTOMER-ORIENTED SME-NETWORK
}

\author{
Wim VANHAVERBEKE ${ }^{*}$ \\ NIBOR \\ University of Maastricht \\ P.O. Box 616 \\ 6200 MD Maastricht \\ The Netherlands \\ Tel.: 0031433883805 \\ Fax: 0031433258495 \\ E-mail: w.vanhaverbeke@mw.unimaas.nl
}

Key words: Regional core competence, inter-organisational networking, customer-oriented business cluster, value added system, value constellation

\begin{abstract}
South West-Flanders is a region in Belgium with an almost unique concentration of firms mainly SMEs - in what could be called the "housing and home furnishing"-business cluster. The extreme geographical concentration of these small and medium sized firms does not translate itself into a sustainable competitive advantage as has been illustrated for other industries in different countries. A critical analysis shows that the lack of commercial success is a direct consequence of the non-existence of networking strategies among these SMEs: Strategies are strictly defined within the firms' boundaries, fierce competition erodes profit margins and new ways of competing remain unexplored. The paper demonstrates that the establishment of innovative networking strategies such as a customer oriented SME network could regenerate the regional economy and transform the existing geographical concentration of firms into a growing and profitable SME network. The network concept is not production or technological oriented, as has been illustrated in for other regions by many scolars. The critical role of an explicit regional development policy and the local institutions in the initial phase is also analysed. The usefulness of the combining concepts such as networking strategies among SMEs, business clusters and regional development is illustrated by means of examples from other industries and countries.
\end{abstract}




\section{REALIZING NEW REGIONAL CORE COMPETENCE: ESTABLISHING A CUSTOMER-ORIENTED SME-NETWORK}

\section{Introduction}

The cluster concept has received renewed interest among economists since the early nineties (Porter (1990); Krugman (1991), Arthur (1990), Malmberg and Maskell (1997), Appold (1997)). There are different ways to conceive business clusters. Usually, geographically bounded business clusters have been explained by marshallian externalities related to factor markets and intermediate input markets, technological externalities, agglomeration externalities, network externalities, market demand effects and public infrastructure.

This paper shows that contemporary developments in corporate strategy design allow to conceive geographically concentrated clusters or networks of firms in still different ways. The approach we will focus at is the customer-oriented approach. It is related to recent criticism on the concepts of value chain and value system as they have been defined by Porter $(1985,1990)$. Normann and Ramirez $(1993,1998)$ introduced the concept 'value constellation'. This concept replaces the value system concept. The latter defines value creation in terms of buying inputs, adding value to it and selling it to the next link of the chain. Organisational boundaries are basically defined by make-buy decisions and there is no apparent need for more complex, or changeable linkages between the firms belonging to a particular value system. Within the value constellation concept companies do not just add value but they reinvent it by means of a reconfiguration of the roles and relationships among actors of the same value creating system. Within this logic, networking and inter-organisational relationships become central pieces of corporate strategy design.

The study of Normann and Ramirez $(1993,1994)$ focuses on large firms that have the financial and strategic opportunities to develop a well thought-out interactive strategy. In this paper we focus on the possibilities of networked SMEs to set up similar competitive value creating systems. This requires a customer-oriented SME network which differs significantly from the traditional clusters where the SMEs reap benefits from different types of externalities. The suggested solutions how to set up a customer oriented SME network are strongly related to the literature about learning regions and the social embeddedness theory (Grabher, 1993; Uzzi, 1997) .

The concept of a customer oriented SME network will be applied to the SMEs in South-West Flanders - a region in Belgium with a typical endogenous growth pattern - in what may be called the "construction and home furnishing" business cluster. This is a Belgian industrial district showing remarkable similarities with the well known cases such as Emilia-Romagna, Baden-Württemberg, or Wales. The geographical concentration of these firms does not automatically generate a sustainable competitive advantage for most of them through the socalled agglomeration economics. I intend to show that the use of a proactive economic policy based on the strategy of networking among local SMEs may significantly improve the economic viability of these firms.

The paper is structured as follows. First, a short review is given of the different interpretations 
of the business cluster concept. Second, the concept of interactive strategy and its consequences for network-wide competence building is analysed in greater detail. Next, the geographical concentration in South-West-Flanders of the firms in the "construction and home furnishing" business cluster will be analysed. A customer-oriented SME-network strategy will be developed in the fourth section. Conclusions are drawn in a final section.

\section{A theoretical framework for customer oriented business clusters}

Business clusters have been defined in different ways. Jacobs and de Man (1996) present an overview of the different approaches in the literature of what clusters are. They distinguish three broad definitions of clusters, each emphasising different dimensions.

The first definition is what could be called "regional clusters". The oldest illustration of this approach are Marshall's industrial districts (1890), which have been updated and modernised by Krugman's (1991) recent work on economic geography. In a similar way, Porter's analysis (1990) focuses on the geographical concentration of strong performing firms in particular sets of related industries. Arthur (1990) focuses on the impact of the agglomeration externalities leading to a geographical concentration of firms. These and other authors mainly focus on two implications of the clustering phenomenon. First, they analyse the driving factors that generate a sustainable competitive advantage for most firms active within the cluster. Second, some authors have paid attention to the implications of the difference in geographical scale of both production networks and markets (Kusters and Minne (1992); Jacobs et al. (1990)).

The second definition analyses the vertical relations existing between companies. It is the main focus of the filière-approach in France and Porter's concept of the value system (Porter (1985)). Similarly, one could focus on the horizontal linkages between firms as several sectors may be part of a cluster or on lateral relations through which different sectors share certain capabilities and in that way reap economies of scope.

The third approach focuses on aggregations of connected sectors within an economy. Porter (1990) has developed a standardised quantitative method to find clusters that emphasise an end-user perspective. He discerns 16 possible clusters and within each cluster he distinguishes four levels: primary goods, machinery for production, specialty inputs and associated services. The interesting point of his approach is that it crosses the classical division of the economy into industrial sectors and services. It has frequently been observed that the competitive advantage of regions in particular sets of industries is the result of complementary and mutually reinforcing specialisations in industrial and service sectors.

Another useful definition of a cluster - the one that will be used in this paper - is based on the "value-creating system" concept developed by Normann and Ramirez (1993, 1998) and Ramirez (1999). These authors argue that the concepts of value chain and value system are outmoded and that global competition, changing markets, and new technologies are opening up completely new ways of creating value. The focus of the new strategic analysis is not the company or industry but the value-creating system, within which different economic actors suppliers, business partners, allied customers - work together to co-produce value. Their key strategic task is the reconfiguration of roles and relationships among this constellation of actors in order to mobilise the creation of value in new forms and by new players (Normann and 
Ramirez (1993, p. 66)). As a consequence, every product or service (offering) is the result of a complicated set of activities between and relationships among actors within the value-creating system.

This new logic of value has significant implications for the firm strategy. First, as value is created within complex constellations, competition is no longer between firms but between offerings, which are, in turn, the result of the cooperation between companies. Second, as offerings become more complex and varied, so do the relationships necessary to produce them: stand-alone strategies are no longer viable and most attractive offerings imply strategies of networking by different economic actors. Third, the only true source of competitive advantage is to conceive and implement the entire value-creating system. This implies that companies must continuously reassess and redesign their competence and relationships based upon a thorough understanding of how customers may create value for themselves starting from the offerings.

The Normann and Ramirez (1993, 1998) concept of business clusters is basically customeroriented. The difference between their publications and the present article is that in the former a number of examples are presented in which a large company takes the lead in shaping the network, while the absence of a large company is essential in the present approach. The role of a leading firm is replaced by a handful of associations or independent platforms. However, the way how these platforms work is completely different than the purposive network design of a leading firm. As we will see, these associations and platforms may have an impact on local SMEs by changing the economic and socio-cultural environment in which they are embedded. The local untraded interdependencies between firms might be a crucial factor for the realisation of this switch Storper (1995). The establishment of a customer-oriented network between the SMEs inside the "construction and home furnishing" business is a necessity in order to stay competitive: this, in turn, implies a change in the managerial and social routines.

\section{Value creating systems and their consequences for inter-organisational networking}

Inter-organisational networking has been a hot issue for more than a decade. However, the relation between the purposive design of a customer oriented interactive business strategy and inter-organisational networking has received much less attention. This paper intends to combine both literature strands in order to come up with a new and viable customer oriented type of network between SMEs.

In the traditional thinking about value (Porter, 1985, 1990) every company occupies a position within on the value system. From this perspective, companies sequentially add value to the inputs before passing them to the next actor in the chain. Within this unidirectional, sequential arrangement, organisational boundaries are basically defined by make or buy decisions: depending on market transaction costs and possible scale and scope advantages a producer will choose for vertical integration or buying inputs from a supplier. The unit of analysis for strategy making is the company or strategic business unit and its main focus is competition amongst them and the strategic positioning of each of them. Managing and organising requirements restricted to activities within the organisational boundaries: There was no apparent need to co-ordinate activities beyond organisational boundaries. 
Porter's value chain has been accepted as the basic framework to analyze the logic of firm-level value creation. Only recently it has been challenged. Stabell and Fjeldstad (1998) argue that the value chain is only one of the three generic value configuration models: the value chain framework is well suited to describing and understanding a traditional manufacturing company but not service companies. The shortcomings of the value chain concept are also critizise by Normann and Ramirez (1993,1998) and Ramirez (1999) introduced the concept 'value constellation'. This concept replaces the value system or value chain idea. The latter defines value creation in terms of buying inputs, adding value to it and selling it to the next link of the chain. With the chain concept, value creation is sequential and value is simply added by distinct producers. Organisational boundaries are basically defined by make-buy decisions and there is no apparent need for more complex, or changeable linkages between the firms belonging to a particular value system.

They offer an alternative view of value creation, 'value co-production'. Within this framework not companies compete with each other but different products / services (they call it 'offerings') compete for the time, attention and money of the customers. Value occurs not in sequential chains but in complex constellations of economic transactions and institutional arrangements among the different actors in the value-creating system (Normann and Ramirez : 1993, p.68). Relations in co-production are more complex, more multi-directional and simultaneous than those described by the value chain. Actors in the value-creating system produce value together through rethinking their interrelationships. Therefore, value creation is not just adding value but reinventing it by means of a reconfiguration of the roles and relationships among actors of the same value creating system. Within this logic, networking and inter-organisational relationships become central pieces of corporate strategy design.

'Offerings' act as the boundary where actors come together to co-produce value. Actors "... allocate the tasks involved in value creation among themselves and to others, intime and space, explicitly or implicitly. This opens up many opportunities for defining relationships between actors and reassigning activities." (Normann and Ramirez : 1998, p. 54). New technologies, globalization and changing markets open up new value-creating options, forcing firms to reconfigure their constellations and changing the value-creation logics of the past in a radical way. These changes are so overwhelming that firms have to redefine their interfaces and to reconsider their organisational structures. Mananging across boundaries is becoming a critical skill as companies can only offer a comtetive offering by means of increasingly complex inter-organizational relationships (Hirschhorn and Gilmore, 1992). Other authors focussing on inter-organisational systems emphasise the need to redesign the business network and to redefine the business scope (Venkatraman, 1994).

The study of Normann and Ramirez $(1993,1998)$ focuses on large firms that have the financial and strategic opportunities to develop a well thought-out interactive strategy. In this paper we focus on the possibilities of networked SMEs to set up similar competitive value creating systems. This requires a customer-oriented SME network which differs significantly from the traditional clusters where the SMEs reap benefits from different types of externalities (Krugman, 1991). The suggested solutions how to set up this a customer oriented SME network, are strongly related to the literature about learning regions and social embeddedness (Uzzi, 1997; Grabher, 1993). 


\section{The "construction and home furnishing"business cluster in South-West Flanders}

The "construction and home furnishing" business cluster is a concept emphasising the end-user perspective and it is based on the previously mentioned concept of strategy by Normann and Ramirez (1993): those industries have been selected that produce value-creating offerings for the customers' "construction and home furnishing" needs. They represent a set of industries that constitute the value-creating system from the customers' point of view.

South-West Flanders is a region in Belgium with an almost unique concentration of small and medium-sized firms in the "construction and home furnishing" business cluster. Table 1 shows that almost $30 \%$ of the gross regional product is realised by firms within this cluster. Even if only $50 \%$ of the value added by the industries mentioned in table 1 is fully related to activities of "construction and home furnishing", the local economic weight of this cluster is still quite impressive.

\section{Insert table 1 here}

Six variables are calculated per industry. The first column represents the value added in Belgian Francs in 1995. The second column stands for the share of the region as compared to the total value added in Belgium by that particular industry. The third one is simply the share of this industry within the gross regional product. The fourth column represents the specialisation index ${ }^{1}$. Values larger than 100 indicate a concentration of the corresponding economic activity in this region. The region is clearly specialised in this set of industries: a weighted average of the specialisation index indicates that the share of the gross regional product generated by these industries is more than six times higher as compared to the rest of Belgium. The fifth column represents the annual growth rate of the value added by each industry during the period 1985-1995. The relative growth compares the regional growth rate to that of the whole country: the added value of regional firms within this cluster has also grown 3\% faster during that period as compared to similar firms in the rest of Belgium. The cluster is almost exclusively made up of SMEs. The mere existence of a regional cluster does not necessarily mean that there is a network of co-operative agreements between these firms. The "construction and home furnishing" business cluster in South-West Flanders illustrates this quite nicely : firms are following a stand-alone strategy and co-operative agreements are exceptional. Networking strategies between firms do not exist as nearly all transactions between them are between 'arm-length' relations. However, companies are linked indirectly to each other through informal contacts and kinship relations. Business associations and fares are also a meeting place for SME-managers within a particular industry.

In table 1 we find the carpet industry and soft furnishings industry, the furniture industry, the

1 The specialisation index can be formulated as follows:

(Share of industry $i$ in the total value added (VA) of the sub-region) $x 100$

(Share of industry $i$ in the total value added (VA) of the reference country)

The industry classification which we applied is the NACE-3 digit classification. The sub-region is South-West Flanders and the reference country is Belgium. 
various sectors of the building industry as such, the plastic processing industry, the wood industry, some businesses within the wholesale trade, building materials and bricks, carpentry and parquet floors, etc.. It is important to mention that table 1 only gives a representation of the most important sectors. We have deliberately chosen to exclude minor sectors such as lighting products (VA: 190, 323), the processing and handling of natural stone (VA: 158,004) and the hiring out of machines and pieces of equipment for the building industry (VA: 91,801). Further, all retail trades involving "construction and home furnishing" have not been taken into account. Moreover, all major (and often highly specialised) related or supporting sectors (such as textile machines, textile refinery, etc.) have been kept out of the table. And, finally, not all potential services to support this set of sectors have been counted in : examples are specialised logistic services, bureau's of technical counseling, bureau's of design, architects, marketing bureau's, accountants, etc.. Three of the major characteristics of this set of sectors must be mentioned, though. First, it should be noted that these sectors are labour-intensive and the their commercial competence is partly interwoven with the craftsmanship of technically skilled workers. Second, the sub-regional competence within each of the sectors involved is not constituted by one predominant company, but by a large group of highly performing SMEs. Their competence often results from their experience of many years' standing within a competitive market environment. Finally, it should be mentioned that the power of decision within these sectors has remained concentrated in South-West Flanders, because nearly all of these companies have been started up with regional capital and are managed by their own locally rooted management teams.

Although the geographical concentration and the growth rate of these firms is fairly impressive, throat-cutting competition squeezes profits considerably. Moreover, companies do not have an explicit strategy focussing on a sustainable competitive advantage: competition is usually pricebased and almost all firms, followers of trends as they are, use "copycat" strategies. Companies are complaining about the increased competition from foreign companies since the completion of the internal market within the E.U.. They are also facing considerable problems when trying to enter the market of Northern France (which is at a distance of less than 50 kilometres). Finally, many small companies have uttered their fears about the growing market penetration of large foreign companies.

The competitive advantage of these firms is based on a few firm characteristics that are partly the result of the social and cultural context in which these firms are embedded (Uzzi (1997)).

The main economic and social characteristics of the region could be summarised as shown in figure $1^{2}$.

\section{Insert about here figure 1}

The economy of the region is characterised by an endogenous growth process - or an autonomous industrialisation process - driven by local entrepreneurship and family capital. Almost all companies are SMEs with an extremely flat organisation structure. This basically allows firms to be very flexible and to react rapidly to changes in the market. As a result of this, most firms are also specialised in markets in which products are custom-made. 
Firms located in the region have a comfortable position in a number of industries where these characteristics may be translated into sustainable competitive advantage. Examples are the textile industry, the food processing industry, furniture and other wooden articles, plastic products, installation firms, etc.. This has led to a remarkable specialisation pattern within the region - concentration of firms in certain industries -, with agglomeration economies playing a role in several of these industries.

But firms based in South-West Flanders are also facing considerable drawbacks. Competition amongst the companies is fierce and is price-based. Co-operation between them is almost nonexistent. Their competitive strength lies almost exclusively in their production techniques. Most firms are not acquainted with R\&D-activities or marketing strategies. They do not have the critical size to develop competitive distribution networks, and they are by no means trendsetters as far as design is concerned. Most of them also lack the size and skills necessary to build a network of co-operative agreements which could help them overcome their competitive disadvantage in value activities such as $\mathrm{R} \& \mathrm{D}$, design, logistics, distribution and marketing.

\section{From cluster to network ${ }^{3}$}

Examples from the past indicate that individual corporate efforts - and especially those of SMEs - are too small to alter competitive conditions. Most companies agree that a change may only be enforced by actions at the level of the industry or at the level of the entire cluster. A regional economic policy focusing on strategies of networking among firms is one of the instruments that could activate the economic potential of the "construction and home furnishing" business cluster.

In order to revamp this business cluster, it should be regional policy to make firms sensitive as to how they may create value for the final customer. The latter could be defined as the individual who is looking for competitive offerings that fit his need to build and furnish a home for himself or the manager who wants to establish or fit up offices or industrial buildings. Creating value for the final customer should not remain confined to value activities such as production and installation - present competitive strengths of these firms. Creating value is (mis)understood by most firms as the mere production and installation of a product. New and highly qualitative ways of creating value could be opened up, if firms are willing to reformulate their competitive strategy redefining their business scope to the whole range of value activities in a consistent and customer-oriented way (see figure 2). However, taking advantage of value activities such as R\&D, design, distribution and marketing requires of SMEs to engage in cooperative agreements and to get involved in industry- or cluster-wide networks.

\section{Insert about here figure 2}

As we cannot elaborate on each of these value activities, a summary of two value activities product development and design on the one hand, and distribution and marketing on the other hand - is given in the following sections.

3 This part of the paper summarises the findings of Vanhaverbeke (1995). 


\subsection{Product development and design ${ }^{4}$}

Most firms in the "construction and home furnishing" business cluster have been imitators instead of innovators or trendsetters. This copy-cat mentality easily degrades into price competition, which generates destructive competition among the Belgian firms, given their high labour costs and the labour-intensive nature of most of these industries. Furthermore, the reputation of craftsmanship and the production of high-quality products no longer suffices to cope with foreign competitors within an increasingly dynamic and globalised environment.

The role of product development and design is becoming more and more important to the industries related to "construction and home furnishing". These two value activities are situated at the meeting-point of technical capabilities and preferences related to the lifestyle of the final customer. They are the two best-suited value activities by which a product line may be differentiated from that of foreign competitors. They also constitute the backbone of a possible inter-firm network covering the entire "construction and home furnishing" business cluster, and changing the copy-cat mentality into an attitude of innovation and creativity. The advantage of this strategy of networking is that firms belonging to the cluster will considerably expand their range of action and the number of their customers.

This strategy of networking may be found under various forms. One initiative that has recently been developed is CePRO. CePRO presents itself as an independent platform for the coordination, promotion and centralisation of activities within the field of product development and design. It develops a wide range of activities: technology diffusion intended for SMEs, disseminating information about new materials, scanning the latest trends in markets sensitive to fashion, offering a window for innovative "products for the interior", etc..

\subsection{Distribution and marketing}

Next to design, distribution and marketing are the most important value activities on which the regional economic strategy should concentrate its efforts. Newly developed products and designs will remain unnoticed by the customer unless supported by a well-structured distribution and marketing strategy. To put it differently, marketing and distribution strategies must guarantee access to the customer.

Distribution practice in most industries of the "construction and home furnishing" business cluster is changing rapidly. Large distribution chains are taking over the role of traditional wholesalers and retailers. Furthermore, most markets have switched from a sellers-market to a buyers-market. As a result, distribution channels are nowadays squeezing the profits made by manufacturers. Reactions from established distribution channels and manufacturers in SouthWest Flanders have mostly remained defensive and ineffective. Only a proactive distribution strategy for major parts of the cluster may cope with the growing competition of wellorganised foreign distribution chains 5 .

\footnotetext{
4 In this context product development can be defined as the use of new materials and technologies, the refinement of production processes, etc ... Design deals with the detection of new trends, the creation of new concepts, the creativity regarding interior decoration, etc. .

5 For a more detailed study see Van der Laan (1995).
} 
Distribution strategies may only be effective if they are elaborated together with promotional strategies. The latter need to inform the final customers about new offerings and should promote the region as a centre of excellence regarding "construction and home furnishing". A well-thought out promotional strategy using special events and existing regional platforms could provide the region with a well-suiting image. We cannot go into details here, but the promotional strategy requires of firms to build networks resulting into cluster-wide promotional activities.

\section{How to develop a customer-oriented SME-network?}

The "value constellation" concept of Normann and Ramirez $(1993,1998)$ shows that designing interactive strategies over the whole value system and managing across organisational boundaries is becoming a critical skill. In many industries firms have to reconfigure their business system or they will be reconfigured by more dynamic competitors. The example of the "construction and home furnishing" business cluster in South-West Flanders illustrates how traditional competitive strengths, based upon craftmanship, flexibility and customised services, can be undermined by competitors that are highly organised within a customer-oriented business network. Their 'offerings' have proven to be more attractive (competitive) than those of the SMEs in South-West Flanders whose interactions along the value system are can be characterised as mere market transactions.

The crucial question is how hundreds of SMEs can be pulled into an interactive strategy resulting into a customer oriented network that stands for a quantum-leap in the value-creating system. Normann and Ramirez offer only cases of large firms who have the financial power to reshape a whole industry by designing an interactive strategy for a whole range of companies over the entire value-creating system. However, there is one interesting exception, the 300 independent Danish pharmacists and their national association (the Danish Pharmaceutical Association). Facing a deregulation of the drugs market they were looking for opportunities to reposition their offerings and thus reconfigure their business. The interesting point here is that not only large companies but also business associations, regulatory bodies and other institutions can play a crucial role in setting up a customer-oriented network. However, the difference with the "construction and home furnishing" business cluster in South-West Flanders is that this industry cuts across industry boundaries and that associations and other institutions do not have the same tight grip on the companies as the Danish Pharmaceutical Association has on the pharmacists.

\section{Conclusion}

There are several ways to define business clusters. The "value-creating system" concept of Normann and Ramirez (1993) is interesting because it offers a theoretical framework to define 
customer-oriented interfirm networks. Customer-oriented business clusters may be extracted from regional economic statistics, but the corresponding geographical concentration of economic activities does not imply that the firms involved establish networks of cooperative agreements.

This has been illustrated by the "construction and home furnishing" business cluster in SouthWest Flanders. The strong geographical concentration of SMEs in this set of industries does not offer the firms any sustainable advantage within a rapidly changing and globalised environment. The basic problem is that these SMEs underestimate the complexity of their relationships with the final customer: they only pay attention to the production of high-quality products and a quick installation procedure without considering how their offerings may create value for the final customer. Product development, design, distribution and marketing are value activities that are not or poorly developed. Upgrading these value activities requires strategies of networking among firms belonging to the business cluster. The networking strategies of the SMEs should also be linked to regional economic policies and to the establishment of independent platforms, because individual corporate efforts do not have the critical size to change the competitive environment. 
References

Appold, J. (1997); "Agglomeration, interorganizational networks, and competitive performance in the U.S. metalworking sector", Economic Geography, Vol. 71, No. 1, pp. 27-54.

Arthur, W. (1989); "Competing technologies, increasing returns, and lock-in by historical events", Economic Journal, 99, pp. 116-131.

Ashkenas, R. et al. (1995); The bounderyless organization, Jossey-Bass: San Francisco, 347 p.

Grabher, G. (1993); Rediscovering the social in the economics of interfirm relations, in: Grabher, G. (ed.), The embedded firm: On the socioeconomics of industrial networks, Routledge: London, pp. 1-32.

Hirschhorn, L. and T. Gilmore (1992); "The new boundaries of the 'boundaryless' company", Harvard Business Review, May-June, 70 (3), pp. 104-115.

Jacobs, D., P. Boekholt and W. Zegveld (1990); De economische kracht van Nederland, SMO: The Hague.

Jacobs, D. and A-P. de Man (1996); "Clusters, industrial policy and firm strategy: A menu approach", Technology analysis and strategic management, Vol. 8, No. 4, pp. 425437.

Krugman, P. (1991); Geography and trade, Leuven University Press and MIT Press : Leuven, Cambridge, MA, $142 \mathrm{p}$.

Kusters, A. and B. Minne (1992); Technologie, marktstructuur en internationalisatie, CPB: The Hague.

Malmberg, A. and P. Maskell (1997); "Towards an explanation of regional specialization and industry agglomeration" European Planning Studies, Vol. 5, No. 1, pp. 25-41.

Marshall, A. (1890); Principles of Economics, MacMillan Press: London.

Maskell, P and A. Malmberg (1997); "Localised learning and industrial competitiveness", Cambridge journal of economics, $\mathrm{pp} . \mathrm{xxx}$

Moore, J. (1996); The death of competition: Leadership and strategy in the age of business ecosystems, Harper Collins: New York.

Musyck, Bernard (1995); "Autonomous industrialization in South West Flanders (Belgium): Continuity and Transformation”, Regional Studies, Vol 29.7, pp. 619-633.

Normann, R. and R. Ramirez (1993); "From value chain to value constellation: Designing interactive strategy", Harvard Business Review, July-August, 71 (4), pp. 65-77.

Normann, R. and R. Ramirez (1998); Designing interactive strategy, Wiley: Chichester, 159 p.

Porter, M. (1985); Competitive advantage: Creating and sustaining superior performance, Free Press: New York, 557 p.

Porter, M. (1990); The competitive advantage of Nations, MacMillan Press: London, 855 p.

Ramirez, R. (1999); "Value co-production: Intellectual origins and implications for practice and research", Strategic Management Journal, 20, pp. 49-65.

Stabell, C. and $\varnothing$. Fjeldstad (1998); "Configuring value for competitive advantage: On chains, shops, and networks", Strategic Management Journal, 19, pp. 413-437.

Storper, M. (1995); "The resurgence of regional economies, ten years later: The region as a nexus of untraded interdependencies", European urban \& regional studies, 2, pp. 191-221.

Uzzi, B. (1997); "Social structure and competition in interfirm networks: The paradox of embeddedness", Administrative Science Quarterly, Vol.42., No. 1, pp.

Van der Laan, Y. (1995); “Construction and furnishing”: A strategy for South West-Flanders, 
Maastricht, unpublished thesis, $73 \mathrm{p}$.

Vanhaverbeke, W. (1995); "Bouwen en wonen": een project voor het realiseren van nieuwe subregionale kerncompetenties in Zuid West-Vlaanderen, Meteor: Maastricht, 24 p.

Vanhaverbeke, W. (1996); Tertiarisering in een industriële regio: Een strategische visie op en beleidsprioriteiten voor Zuid West-Vlaanderen, mimeo, Charter 99, Kortrijk/Maastricht, 185 p.

Vanhaverbeke, W. (1998); Een regio-strategie voor Zuid West-Vlaanderen, REBAK: Kortrijk, $112 \mathrm{p}$.

Venkatraman (1994); "IT-enabled business transformation: From automation to business scope redefinition", Sloan Management Review, Winter, pp. 73-87. 
Tabel 1: The "construction and home furnishing cluster in West-Flanders"

other floor coverings
spitals \& other buildings
roducts
ilding materials
'hold goods, hardware \& iron-mongery
lucts (incl. assemnly \& installation)
plaster products for constructional purposes
istructional purposes
y components and parquet flooring
d other made-up textile goods
Irniture)

\begin{tabular}{|c|c|c|c|c|c|}
\hline $\begin{array}{c}\text { Value added } \\
1994\end{array}$ & $\begin{array}{c}\text { Share } \\
\text { Nace } \\
\text { B elgium }\end{array}$ & $\begin{array}{l}\text { Share } \\
\text { w.r.t. } \\
\text { region }\end{array}$ & $\begin{array}{l}\text { Specia- } \\
\text { lisation- } \\
\text { index }\end{array}$ & $\begin{array}{c}\text { Growth } \\
\text { region }\end{array}$ & $\begin{array}{l}\text { Relative } \\
\text { growth }\end{array}$ \\
\hline in BEF & $\%$ & $\%$ & $\%$ & $\%$ & $\%$ \\
\hline 13278732 & 63.60 & 5.96 & 1380 & 13.08 & 7.85 \\
\hline 7613964 & 30.33 & 3.42 & 658 & 7.21 & 3.48 \\
\hline 6163769 & 7.72 & 2.77 & 168 & 7.67 & -5.27 \\
\hline 5543963 & 15.63 & 2.49 & 339 & 12.71 & 1.10 \\
\hline 5477716 & 11.74 & 2.46 & 255 & 14.63 & 7.87 \\
\hline 5284446 & 67.40 & 2.37 & 1462 & 12.34 & 2.08 \\
\hline 3403621 & 8.59 & 1.53 & 186 & 15.02 & 3.10 \\
\hline 3296743 & 10.45 & 1.48 & 227 & 4.55 & -4.08 \\
\hline 2572162 & 6.84 & 1.15 & 148 & 7.56 & -0.72 \\
\hline 2428104 & 9.92 & 1.09 & 215 & 6.58 & -1.51 \\
\hline 2193224 & 4.77 & 0.98 & 103 & 9.98 & 3.56 \\
\hline 1884068 & 8.81 & 0.85 & 191 & 6.95 & -1.17 \\
\hline 1672286 & 37.95 & 0.75 & 823 & 10.69 & 8.73 \\
\hline 1378166 & 5.57 & 0.62 & 121 & 5.27 & 4.64 \\
\hline 1021461 & 22.72 & 0.46 & 493 & 20.49 & 11.26 \\
\hline 896073 & 21.89 & 0.40 & 475 & 12.60 & -2.56 \\
\hline 530563 & 32.07 & 0.24 & 696 & 1.98 & -3.48 \\
\hline 470375 & 11.31 & 0.21 & 245 & 14.33 & 9.64 \\
\hline 290399 & 2.29 & 0.13 & 50 & 24.15 & 19.58 \\
\hline 274491 & 36.49 & 0.12 & 235 & 8.46 & -5.76 \\
\hline 205513 & 6.90 & 0.09 & 150 & 5.50 & 11.73 \\
\hline \multirow[t]{2}{*}{65879839} & & 29.57 & 410 & & 3.34 \\
\hline & & & 627 & & 2.96 \\
\hline
\end{tabular}




Figure 1: Critical success factors explaining an endogenous growth region

\section{Socio-economic factors}

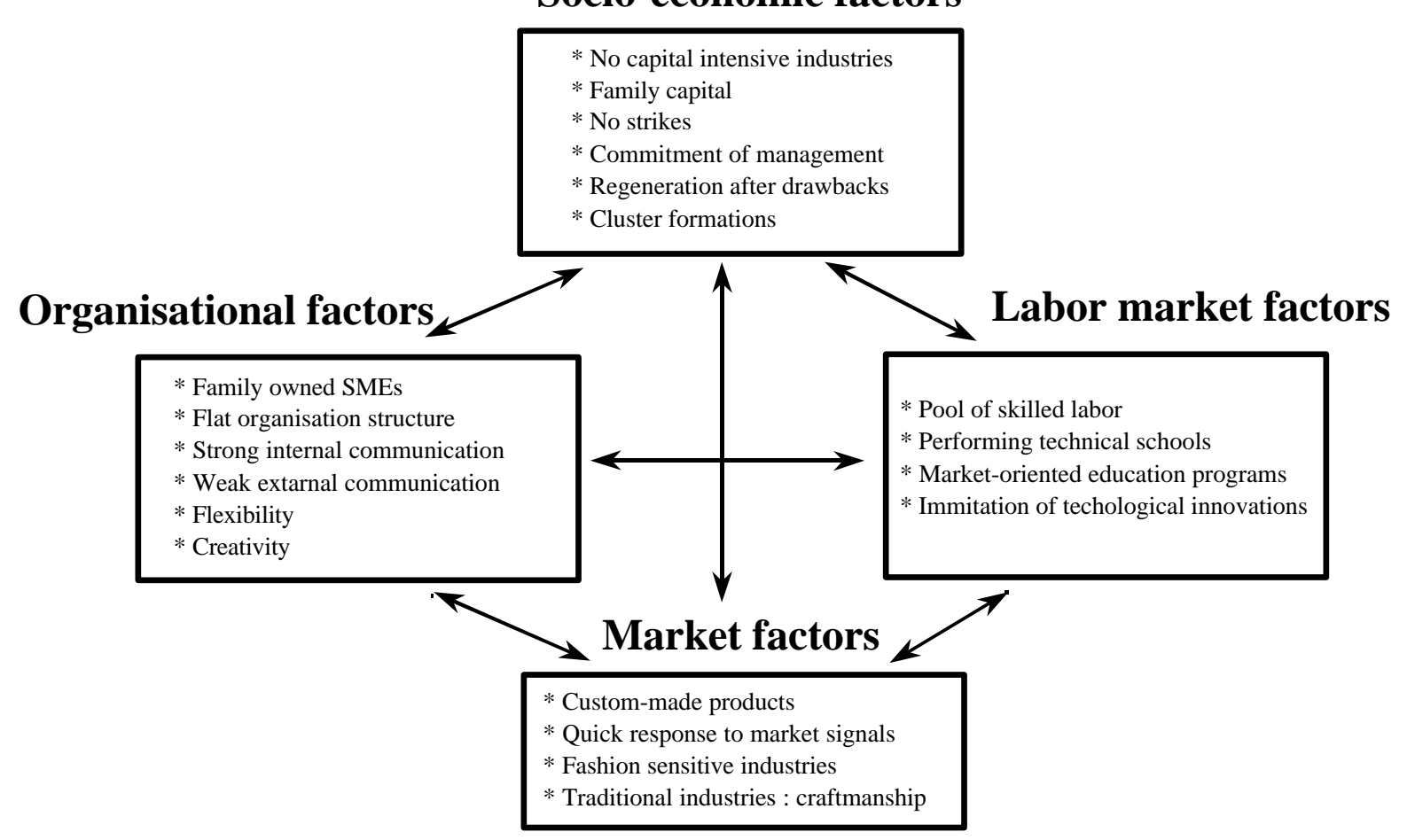


Figure 2: Different dimensions of a regional strategy for "housing and home furnishing"

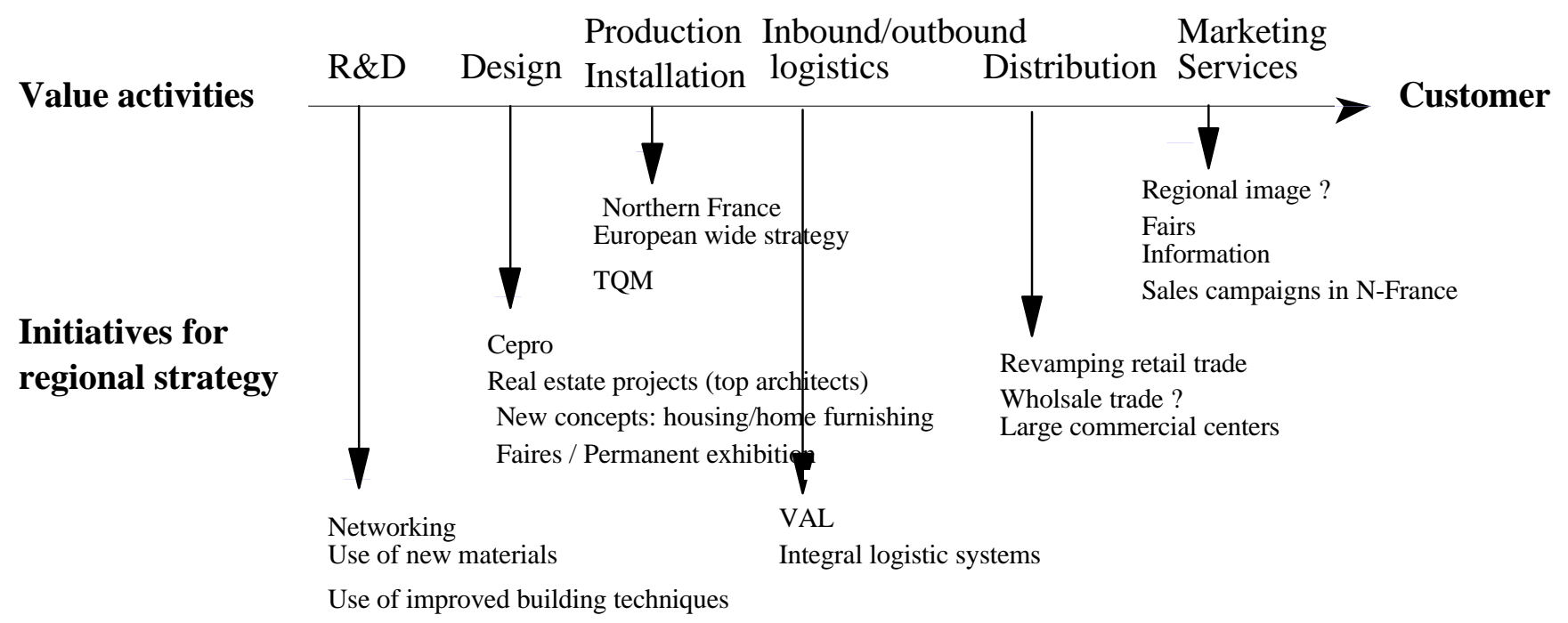


Figure 3: The official cooperation (A) and informal relations (B) between local institutions w.r.t. the export support for SMEs towards Northern France
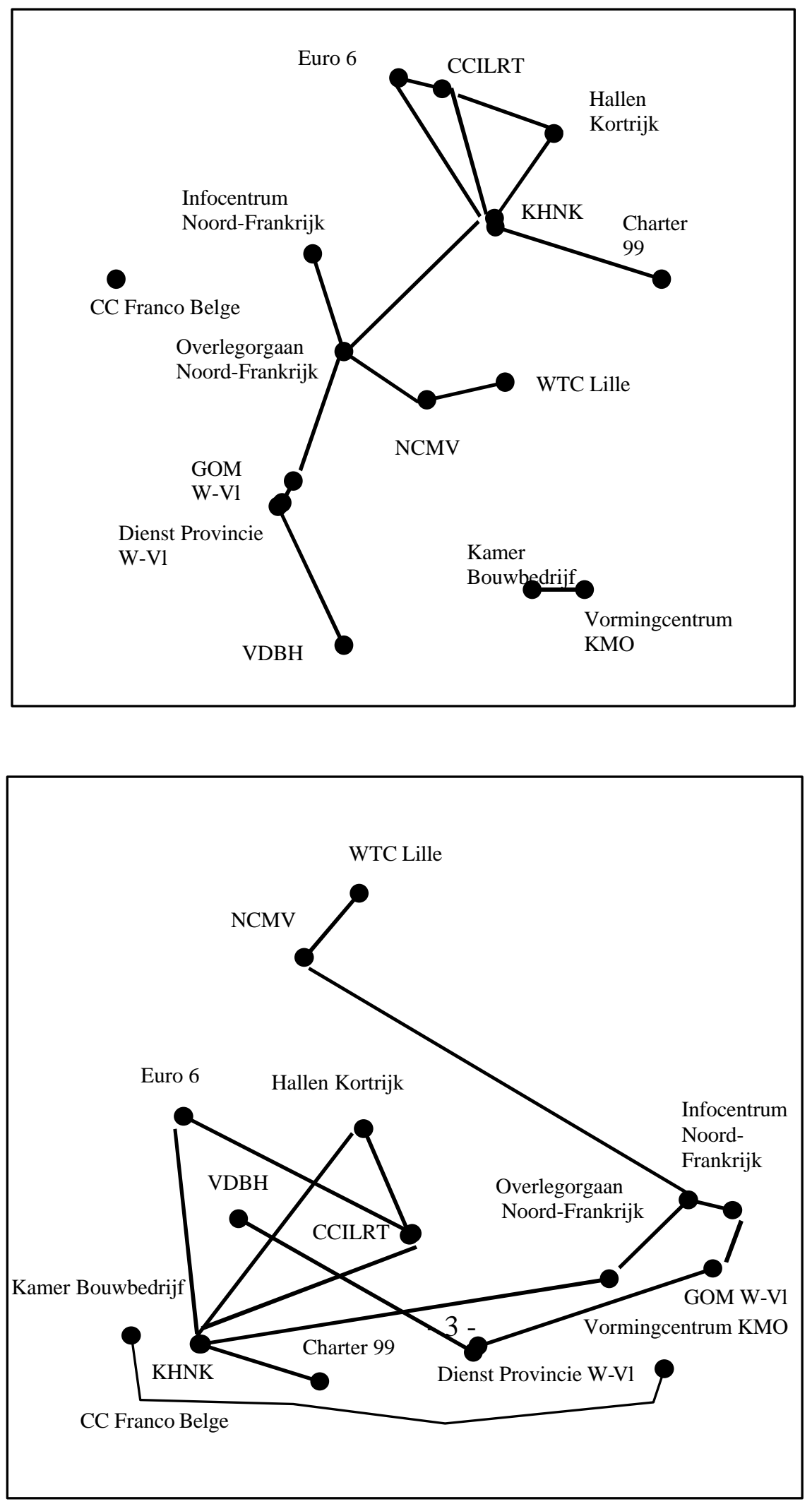